\title{
Maternal Thyroid Dysfunctions and Developing Visual Abnormalities
}

\author{
Ahmed RG* \\ Division of Anatomy and Embryology, Department of Zoology, Faculty of Science, Beni-Suef University, Egypt
}

Submission: March 05, 2018; Published: March 26, 2018

*Corresponding author: Ahmed RG, Department of Zoology, Beni-Suef University, Beni-Suef, Egypt, Tel: 002-010-91471828;

Email: ahmedragab08@gmail.com

Keywords: Maternal thyroid dysfunctions; Vision; Development

Abbreviations: HPTA: Hypothalamic-Pituitary-Thyroid Axis; THs: Thyroid Hormones; T3: 3,5,3'-triiodothyronine; T4: Thyroxine; TR $\alpha$ and TR $\beta$ : Thyroid receptors; PND: Post Natal Day; INL: Inner Nuclear Layer; GCL: Ganglion Cell Layer

\section{Commentary}

The activity of the maternal hypothalamic-pituitarythyroid axis (HPTA) is warranted for the normal development [1-60], especially the morphogenesis and angiogenesis of the retina and its gene expression [61-68]. Regulation the development of the retina by 3,5,3'-triiodothyronine (T3) and thyroxine (T4) is depending on the expression of the thyroid receptors (TR $\alpha$ and TR $\beta$ ) [69-74]. During the prenatal period, Thyroid Hormones (THs) regulate the standard development of the retina and eye [75-78]. During the postnatal period, THs control the differentiation and growth of spectral cone types [79-82]. At the postnatal day (PND) 10, the progress in the levels of THs in the dorsal retina is concomitant with the terminal maturation of the cones [83-87]. Also, expression of TR $\beta 2$ is required for the cones [88-90] to stimulate the expression of Mopsin and to inhibit the expression of S opsinduring the development [91,92] and adulthood [93]. More importantly, the signaling expression of TR $\beta 2$ is vital for the development particularly during the embryonic day 15 to PND 5 [94].

On the other hand, several studies reported that the maternal thyroid dysfunction (hypothyroidism) during the gestation and lactation periods can cause numerous defects as the following $[95,96]$ :

a. Reduce the size of eye;

b. Delay the development of retina;

c. Decrease the cell densities of the inner nuclear layer (INL) and ganglion cell layer (GCL, ganglion cells and displaced amacrine cells); and

d. Abnormalities in the morphology of photoreceptors and inner retina.
In patients with severe Graves' orbitopathy, several authors noticed the abnormalities in the visual acuity [97].

Given these considerations, the current observations proposed that the maternal THs play significant actions in the developing retina, cones, and eye during the prenatal and postnatal periods. The maternal thyroid disorders may directly or indirectly disrupt the morphogenesis and angiogenesis of the retina and its gene expression. This disruption may delay the normal development of the primary visual system and cause retinopathy and neonatal blindness. Additional researchers are needed to allow us to determine the $\mathrm{T} 3$ signaling at the level of individual retinal Cells, in particular, the inner cells during the prenatal and postnatal periods.

\section{References}

1. Ahmed OM, Abd El-Tawab SM, Ahmed RG (2010) Effects of experimentally induced maternal hypothyroidism and hyperthyroidism on the development of rat offspring: I- The development of the thyroid hormones-neurotransmitters and adenosinergic system interactions. Int J Dev Neurosci 28(6): 437-454.

2. Ahmed OM, Ahmed RG (2012) Hypothyroidism. In A New Look At Hypothyroidism. In: Springer D (Eds.), Tech Open Access Publisher, Chapter 1, p. 1-20.

3. Ahmed OM, Ahmed RG, El-Gareib AW, El-Bakry AM, Abd El-Tawaba SM (2012) Effects of experimentally induced maternal hypothyroidism and hyperthyroidism on the development of rat offspring: II-The developmental pattern of neurons in relation to oxidative stress and antioxidant defense system. Int J Dev Neurosci 30(6): 517-537.

4. Ahmed OM, El-Gareib AW, El-bakry AM, Abd El-Tawab SM, Ahmed RG (2008) Thyroid hormones states and brain development interactions. Int J Dev Neurosci 26(2): 147-209.

5. Ahmed RG (2011) Perinatal 2,3,7,8-tetrachlorodibenzo-p-dioxin exposure alters developmental neuroendocrine system. Food Chem Toxicology 49: 1276-1284. 
6. Ahmed RG (2012) Maternal-newborn thyroid dysfunction. In the Developmental Neuro endocrinology, pp. 1-369. Ahmed RG (Ed.) LAP LAMBERT Academic Publishing GmbH \& Co KG, Germany.

7. Ahmed RG (2012) Maternal-fetal thyroid interactions, Thyroid Hormone, Agrawal NK (Eds.), In Tech Open Access Publisher, Chapter 5, pp. 125-156.

8. Ahmed RG (2013) Early weaning PCB 95 exposure alters the neonatal endocrine system: thyroid adipokine dysfunction. J Endocrinol 219(3): 205-215.

9. Ahmed RG (2014) Editorial: Do PCBs modify the thyroid-adipokine axis during development? Annals Thyroid Res 1(1): 11-12.

10. Ahmed RG (2015) Chapter 1: Hypothyroidism and brain development. In advances in hypothyroidism treatment. Avid Science Borsigstr 9, 10115 Berlin, Berlin, Germany. Avid Science Publications level 6, Melange Towers, Wing a, Hitec City, Hyderabad, Telangana, India $\mathrm{p}$. $1-40$.

11. Ahmed RG (2015) Hypothyroidism and brain developmental players. Thyroid Res J 8(2): 1-12.

12. Ahmed RG (2015) Editorials and Commentary: Maternofetal thyroid action and brain development J of Advances in Biology 7(1): 12071213.

13. Ahmed RG (2016) Gestational dexamethasone alters fetal neuroendocrine axis. Toxicol Lett 258: 46-54.

14. Ahmed RG (2016) Neonatal polychlorinated biphenyls-induced endocrine dysfunction. Ann Thyroid Res 2(1): 34-35.

15. Ahmed RG (2016) Maternal iodine deficiency and brain disorders. Endocrinol Metab Syndr 5: 223.

16. Ahmed RG (2016) Maternal bisphenol A alters fetal endocrine system: Thyroid adipokine dysfunction. Food Chem Toxicology 95: 168-174.

17. Ahmed RG (2017) Developmental thyroid diseases and GABAergic dysfunction. EC Neurology 8(1): 2-4.

18. Ahmed RG (2017) Hyperthyroidism and developmental dysfunction. Arch Med 9: 4 .

19. Ahmed RG (2017) Anti-thyroid drugs may be at higher risk for perinatal thyroid disease. EC Pharmacology and Toxicology 4(4): 140-142.

20. Ahmed RG (2017) Perinatal hypothyroidism and cytoskeleton dysfunction. Endocrinol Metab Syndr 6: 271.

21. Ahmed RG (2017) Developmental thyroid diseases and monoaminergic dysfunction. Advances in Applied Science Research 8(3): 1-10.

22. Ahmed RG (2017) Hypothyroidism and brain development. J Anim Res Nutr 2(2): 13

23. Ahmed RG (2017) Antiepileptic drugs and developmental neuroendocrine dysfunction: Every why has A Wherefore. Arch Med $9(6): 2$.

24. Ahmed RG (2017) Gestational prooxidant-antioxidant imbalance may be at higher risk for postpartum thyroid disease. Endocrinol Metab Syndr 6: 279.

25. Ahmed RG (2017) Synergistic actions of thyroid-adipokines axis during development. Endocrinol Metab Syndr 6: 280.

26. Ahmed RG (2017) Thyroid-insulin dysfunction during development. International Journal of Research Studies in Zoology 3(4): 73-75.

27. Ahmed RG (2017) Developmental thyroid diseases and cholinergic imbalance. International Journal of Research Studies in Zoology 3(4): 70-72.

28. Ahmed RG (2017) Thyroid diseases and developmental adenosinergic imbalance. Int J Clin Endocrinol 1(2): 53-55.
29. Ahmed RG (2017) Maternal anticancer drugs and fetal neuroendocrine dysfunction in experimental animals. Endocrinol Metab Syndr 6(6): 281.

30. Ahmed RG (2017) Letter: Gestational dexamethasone may be at higher risk for thyroid disease developing peripartum. Open Journal of Biomedical \& Life Sciences (Ojbili) 3(2): 1-6.

31. Ahmed RG (2017) Deiodinases and developmental hypothyroidism. EC Nutrition 11(5): 183-185.

32. Ahmed RG (2017) Maternofetal thyroid hormones and risk of diabetes. Int J of Res Studies in Medical and Health Sciences 2(10): 18-21.

33. Ahmed RG (2017) Association between hypothyroidism and renal dysfunctions. International Journal of Research Studies in Medical and Health Sciences 2(11): 1-4.

34. Ahmed RG (2017) Maternal hypothyroidism and lung dysfunction. International Journal of Research Studies in Medical and Health Sciences 2(11): 8-11.

35. Ahmed RG (2017) Endocrine disruptors; possible mechanisms for inducing developmental disorders. Int J basic Sci Medicine (IJBSM) 2(4): 157-160.

36. Ahmed RG (2017) Maternal thyroid hormones trajectories and neonatal behavioral disorders. ARC Journal of Diabetes and Endocrinology 3(2): 18-21.

37. Ahmed RG (2017) Maternal thyroid dysfunction and neonatal cardiac disorders. Insights Biol Med 1: 92-96.

38. Ahmed RG (2018) Maternal hypothyroidism and neonatal testicular dysfunction. International Journal of Research Studies in Medical and Health Sciences 3(1): 8-12.

39. Ahmed RG (2018) Maternal hypothyroidism and neonatal depression: Current perspective. International Journal of Research Studies in Zoology 4(1): 6-10.

40. Ahmed RG (2018) Non-genomic actions of thyroid hormones during development. App Clin Pharmacol Toxicol: ACPT-108.

41. Ahmed RG (2018) Maternal thyroid function and placental hemodynamics. ARC Journal of Animal and Veterinary Sciences 4(1): 9-13.

42. Ahmed RG (2018) Interactions between thyroid and growth factors during development. ARC Journal of Diabetes and Endocrinology 4(1): $1-4$.

43. Ahmed RG (2018) Maternal thyroid hormones and neonatal appetite. ARC Journal of Nutrition and Growth 4(1): 18-22.

44. Ahmed RG (2018) Genomic actions of thyroid hormones during development. ARC Journal of Diabetes and Endocrinology 4(1): 5-8.

45. Ahmed RG (2018) Dysfunction of maternal thyroid hormones and psychiatric symptoms. American Research Journal of Endocrinology 2(1): $1-6$.

46. Ahmed RG (2018) Is there a connection between maternal hypothyroidism and developing autism spectrum disorders? ARC Journal of Neuroscience 3(1): 5-8.

47. Ahmed RG (2018) Maternal thyroid dysfunctions and neonatal bone mal development. American Research Journal of Endocrinology (in press) $\mathrm{xx}$-xxx.

48. Ahmed RG (2018) Maternal thyroid disorders and risk of neonatal seizure: Current perspective. ARC Journal of Neuroscience 3(1): 21-25.

49. Ahmed RG (2018) Gestational dioxin acts as developing neuroendocrine-disruptor. EC Pharmacology and Toxicology 6(3): 96100. 
50. Ahmed RG (2018) Maternal thyroid dysfunction and risk of neonatal stroke. ARC Journal of Animal and Veterinary Sciences 4(1): 22-26.

51. Ahmed RG (2018n) Maternal thyroid disorders and developing skin dysfunctions. ARC Journal of Dermatology 3(1): 13-17.

52. Ahmed RG (2018) Maternal hypothyroidism-milk ejections: What is the link? ARC Journal of Nutrition and Growth 4(1): 29-33.

53. Ahmed RG (2018) Does maternal antepartum hypothyroidism cause fetal and neonatal hyponatremia? ARC Journal of Diabetes and Endocrinology 4(1): $\mathrm{xx}-\mathrm{xxx}$

54. Ahmed RG (2018) Maternal hypothyroidism and rheumatoid arthritis. International Journal of Research Studies in Medical and Health Sciences Volume 3(2): 1-5.

55. Ahmed RG (2018) Developmental thyroid and skeletal muscle dysfunction.ARC Journal of Diabetes and Endocrinology 4(1): xx-xxx.

56. Ahmed RG (2018) Hyperthyroidism and renal disorders. ARC Journal of Animal and Veterinary Sciences 4(2): 1-5.

57. Ahmed RG, Abdel-Latif M, Ahmed F (2015) Protective effects of GMCSF in experimental neonatal hypothyroidism. Int Immunopharmacol 29(2): 538-543.

58. Ahmed RG, Abdel-Latif M, Mahdi E, El-Nesr K (2015) Immune stimulation improves endocrine and neural fetal outcomes in a model of maternofetal thyrotoxicosis. Int Immunopharmacol 29(2): 714-721.

59. Ahmed RG, Davis PJ, Davis FB, De Vito P, Farias RN, et al. (2013) Nongenomic actions of thyroid hormones: from basic research to clinical applications. An update. Immunology, Endocrine \& Metabolic Agents in Medicinal Chemistry 13(1): 46-59.

60. Ahmed RG, El-Gareib AW (2014) Lactating PTU exposure: I- Alters thyroid-neural axis in neonatal cerebellum. Eur J of Biol and Medical Sci Res 2(1): 1-16.

61. Ahmed RG, El-Gareib AW (2017) Maternal carbamazepine alters fetal neuroendocrine-cytokines axis. Toxicology 382: 59-66.

62. Ahmed RG, El-Gareib AW, Incerpi S (2014) Lactating PTU exposure: II- Alters thyroid-axis and prooxidant-antioxidant balance in neonatal cerebellum. Int Res J of Natural Sciences 2(1): 1-20.

63. Ahmed RG, El-Gareib AW, Shaker HM (2018) Gestational 3,3',4,4,5-pentachlorobiphenyl (PCB 126) exposure disrupts fetoplacental unit: Fetal thyroid-cytokines dysfunction. Life Sciences 192: 213-220.

64. Ahmed RG, Incerpi S (2013) Gestational doxorubicin alters fetal thyroid-brain axis. Int J Dev Neurosci 31(2): 96-104.

65. Ahmed RG, Incerpi S, Ahmed F, Gaber A (2013) The developmental and physiological interactions between free radicals and antioxidant: Effect of environmental pollutants. J of Natural Sci Res 3(13): 74-110.

66. Ahmed RG, Walaa GH, Asmaa FS (2018) Suppressive effects of neonatal bisphenol A on the neuroendocrine system. Toxicology and Industrial Health Journal (in press).

67. Ahnelt PK, Kolb H (2000) The mammalian photoreceptor mosaicadaptive design. Prog Retin Eye Res 19(6): 711-777.

68. Applebury ML, Farhangfar F, GloÈsmann M, Hashimoto K, Kage K, et al. (2007) Transient expression of thyroid hormone nuclear receptor TRbeta2 sets $\mathrm{S}$ opsin patterning during cone photoreceptor genesis. Dev Dyn 236(5): 1203-1212.

69. Arbogast P, Flamant F, Godement P, GloÈsmann M, Peichl L (2016) Thyroid hormone signaling in the mouse retina. PLoS ONE 11(12): e0168003.
70. Baldeschi L, Wakelkamp IM, Lindeboom R, Prummel MF, Wiersinga WM (2006) Early versus late orbital decompression in Graves' orbitopathy: a retrospective study in 125 patients. Ophthalmol 113(5): 874-878.

71. Candelotti E, De Vito P, Ahmed RG, Luly P, Davis PJ, et al. (2015) Thyroid hormones crosstalk with growth factors: Old facts and new hypotheses. Immun Endoc \& Metab. Agents in Med Chem 15: 71-85.

72. Cheng CL, Gan KJ, Novales Flamarique I (2009) Thyroid hormone induces a time-dependent opsin switch in the retina of salmonid fishes. Invest Ophthalmol Vis Sci 50(6): 3024-3032.

73. De Vito P, Candelotti E, Ahmed RG, Luly P, Davis PJ, et al. (2015) Role of thyroid hormones in insulin resistance and diabetes. Immun Endoc \& Metab Agents in Med Chem 15: 86-93.

74. El-bakry AM, El-Ghareeb AW, Ahmed RG (2010) Comparative study of the effects of experimentally-induced hypothyroidism and hyperthyroidism in some brain regions in albino rats. Int J Dev Neurosci 28(5): 371-389.

75. El-Ghareeb AA, El-Bakry AM, Ahmed RG, Gaber A (2016) Effects of zinc supplementation in neonatal hypothyroidism and cerebellar distortion induced by maternal carbimazole. Asian Journal of Applied Sciences 4(4): 1030-1040.

76. Flamant F, Samarut J (2003) Thyroid hormone receptors: lessons from knockout and knock-in mutant mice. Trends Endocrinol Metabol 14(2): 85-90.

77. Forrest D, Reh TA, Rusch A (2002) Neuro developmental control by thyroid hormone receptors. Curr Opin Neurobiol 12(1): 49-56.

78. Glaschke A, Glosmann M, Peichl L (2010) Developmental changes of cone opsin expression but not retinal morphology in the hypothyroid Pax8 knockout mouse. Invest Ophthalmol Vis Sci 51(3): 1719-1727.

79. Glaschke A, Weiland J, Del Turco D, Steiner M, Peichl L, et al. (2011) Thyroid hormone controls cone opsin expression in the retina of adult rodents. J Neurosci 31(13): 4844-4851.

80. Harpavat S, Cepko CL (2003) Thyroid hormone and retinal development: an emerging field. Thyroid 13(11): 1013-1019.

81. Incerpi S, Hsieh MT, Lin HY, Cheng GY, De Vito P, et al. (2014) Thyroid hormone inhibition in L6 myoblasts of IGF-I-mediated glucose uptake and proliferation: new roles for integrin $\alpha v \beta 3$. Am J Physiol Cell Physiol 307(2): C150-C161.

82. Lyons CJ, Rootman J (1994) Orbital decompression for disfiguring exophthalmos in thyroid orbitopathy. Ophthalmol 101(2): 223-230.

83. Ma H, Thapa A, Morris L, Redmond TM, Baehr W, et al. (2014) Suppressing thyroid hormone signaling preserves cone photoreceptors in mouse models of retinal degeneration. Proc Natl Acad Sci USA 111(9): 3602-3607.

84. Mader MM, Cameron DA (2006) Effects of induced systemic hypothyroidism upon the retina: regulation of thyroid hormone receptor alpha and photoreceptor production. Mol Vis 12: 915-30.

85. Navegantes LCC, Silveira LCL, Santos GL (1996) Effect of congenital hypothyroidism on cell density in the ganglion cell layer of the rat retina. Braz J Med Biol Res 29(5): 665-668.

86. Ng L, Hurley JB, Dierks B, Srinivas M, Salto C, et al. (2001) A thyroid hormone receptor that is required for the development of green cone photoreceptors. Nat Genet 27(1): 94-98.

87. Ng L, Lyubarsky A, Nikonov SS, Ma M, Srinivas M, et al. (2010) Type 3 deiodinase, a thyroid-hormone-inactivating enzyme, controls survival and maturation of cone photoreceptors. J NeuroSci 30(9): 3347-3357. 
88. Ng L, Ma M, Curran T, Forrest D (2009) Developmental expression of thyroid hormone receptor $\beta 2$ protein in cone photoreceptors in the mouse. Neuroreport 20(6): 627-631.

89. Oh SR, Tung JD, Priel A, Levi L, Granet DB, et al. (2013) Reduction of orbital inflammation following decompression for thyroid-related orbitopathy. Biomed Res Int 2013: 794984.

90. Peichl L (2005) Diversity of mammalian photoreceptor properties: Adaptations to habitat and lifestyle? Anat Rec A Discov Mol Cell Evol Biol 287(1): 1001-1012.

91. Pessoa CN, Santiago LA, Santiago DA, Machado DS, Rocha FA, et al. (2008) Thyroid hormone action is required for normal cone opsin expression during mouse retinal development. Invest Ophthalmol Vis Sci 49(5): 2039-2045.

92. Pinazo-Duran MD, Iborra FJ, Pons S, Sevilla-Romero E, GallegoPinazo R, et al. (2005) Postnatal thyroid hormone supplementation rescues developmental abnormalities induced by congenital-neonatal hypothyroidism in the rat retina. Ophthalmic Res 37(4): 225-234.
93. Roberts MR, Srinivas M, Forrest D, Morreale de Escobar G, Reh TA (2006) Making the gradient: thyroid hormone regulates cone opsin expression in the developing mouse retina. Proc Natl AcadSci USA 103(16): 6218-6223.

94. Thut CJ, Rountree RB, Hwa M, Kingsley DM (2001) A large-scale in situ screen provides molecular evidence for the induction of anterior segment structures by the developing lens. Dev Biol 231(1): 63-76.

95. Trimarchi JM, Harpavat S, Billings NA, Cepko CL (2008) Thyroid hormone components are expressed in three sequential waves during development of the chick retina. BMC Devel Biol 8: 101.

96. Van Herck SLJ, Geysens S, Bald E, Chwatko G, Delezie E, et al. (2013) Maternal transfer of methimazole and effects on thyroid hormone availability in embryonic tissues. Endocrinol 218(1): 105-115.

97. Wakelkamp IM, Baldeschi L, Saeed P, Mourits MP, Prummel MF, et al. (2005) Surgical or medical decompression as a first-line treatment of optic neuropathy in Graves' ophthalmopathy?A randomized controlled trial. Clin Endocrinol (Oxf) 63(3): 323-328.

\section{Your next submission with Juniper Publishers will reach you the below assets}

- Quality Editorial service

- Swift Peer Review

- Reprints availability

- E-prints Service

- Manuscript Podcast for convenient understanding

- Global attainment for your research

- Manuscript accessibility in different formats ( Pdf, E-pub, Full Text, Audio)

- Unceasing customer service

Track the below URL for one-step submission https://juniperpublishers.com/online-submission.php 